\title{
Penerapan Asuhan Keperawatan Jiwa Pada Ny. L Dengan Gangguan Konsep Diri : Harga Diri Rendah
}

\section{Ruh Imanita Sihombing, ${ }^{1}$ Andika Rahmat Harefa, ${ }^{2}$ Erma Fitria Samosir, ${ }^{3}$ Sarah Monica, ${ }^{4}$ Sry Nofita Sari Hutagalung, ${ }^{5}$ Yuliana Romayanti, ${ }^{6}$}

\author{
andikarahmat444harefa@gmail.com
}

\section{BAB 1 \\ PENDAHULUAN}

\subsection{Latar Belakang}

Skizofrenia merupakan gangguan mental yang ditandai dengan gangguan proses berpikir dan respons emosional yang lemah. Situasi ini umumnya merupakan gangguan berpikir disertai dengan disfungsi sosial dan bicara kacau balau. Gejala skizofrenia salah satunya negatif yaitu harga diri yang rendah (Pardede, Keliat, \& Wardani, 2020). Skizofrenia menimbulkan distorsi persepsi, emosi, dan tingkah laku sehingga pasien dengan skizofrenia memiliki risiko lebih tinggi berperilaku agresif dimana perubahan perilaku secara dramatis terjadi dalam beberapa hari atau minggu. Hal inilah yang membuat perlunya bantuan keluarga pasien untuk merawat dan memberikan perhatian khusus pada pasien skizofrenia (Pardede \& Hasibuan, 2020).

Berdasarkan data WHO (2013) sekitar 450 juta orang di dunia yang mengalami gangguan jiwa, sebagian besar mengalami skizofrenia. Di Indonesia sebanyak $84,9 \%$ pengidap skizofrenia di Indonesia telah berobat. Data dari 33 Rumah sakit jiwa yang ada di seluruh Indonesia menyebutkan hingga kini jumlah penderita gangguan jiwa berat mencapai 2,5 juta orang (Riskesdas, 2018). Di Sumatera Utara sendiri penderita skizofrenia menduduki peringkat ke 21 dengan nilai privalensi 6,3\%, setelah Provinsi Timur (Kemenkes, 2019). Gejala positif dari skizofrenia termasuk harga diri rendah (Pardede, Hamid \& Putri, 2020) 
Harga diri rendah kronik merupakan salah satu respon maladaptif dalam rentang respon neurobiologi. Proses terjadinya harga diri rendah kronik pada pasien skizofrenia dapat dijelaskan dengan menganalisa stressor predisposisi dan presipitasi yang bersifat biologis, psikologis, dan sosial budaya sehingga menghasilkan respon bersifat maladaptif yaitu perilaku harga diri rendah kronik.Respon terhadap stressor pada pasien harga diri rendah memunculkan respon secara kognitif, afektif, fisiologis, perilaku dan sosial. Respon-respon tersebut akan dianalisis lebih lanjut, sehingga memunculkan rentang respon (Pardede, Keliat, \& Yulia, 2015).

Dalam mengatasi masalah gangguan interaksi pada pasien gangguan jiwa khususnya pasien harga diri rendah dapat dilakukan upaya-upaya tindakan keperawatan bertujuan untuk menerapkan asuhan keperawatan jiwa dengan harga diri rendah dalam upaya meningkatkan harga diri dengan terapi aktivitas kelompok (Hani, Moomina, \& Selpina, 2019). Pasien yang mengalami ganggaun konsep diri: harga dirir rendah harus diberikan terapi non farmakologis agar pasien mampu berinteraksi dengan orang lain seperti, terapi generalis (Strategi pelaksanaan 1-4) yang diberikan melalui asuhan keperawatan jiwa.

Pemberian asuhan keperawatan jiwa pada pasien dengan masalah isolasi sosial berfokus pada membina hubungan saling percaya, memberi kegiatan sesuai dengan kemampuan pasien, meningkatka kontak dengan orang lain, mendorong pasien mengungkapkan pikiran dan perasaan serta membantu melihat prestasi, kemampuan dan harapan pasien. Survei awal yang dilakukan untuk pemberian asuhan keperawatan pada pasien skizofrenia ini dilakukan di Yayasan pemenang jiwa Sumatera dengan jumlah pasien 70 orang tetapi yang menjadi subjek adalah 1 orang dengan pasien isolasi sosial pada Ny. L. 


\subsection{Rumusan Masalah}

Berdasarkan latar belakang masalah tersebut maka dapat dirumuskan masalah sebagai berikut : bagaimana pemberian asuhan keperawatan jiwa pada Ny. L dengan harga diri rendah di yayasan pemenang jiwa sumatera.

\subsection{Tujuan}

Adapun tujuan nya sebagai berikut :

\subsubsection{Tujuan Umum}

Setelah mengikuti kegiatan ini klien dapat lebih menerapkan strategi pelaksanaan Harga Diri Rendah Kronis dalam mengontrol Perilaku Harga Diri Rendah

\subsubsection{Tujuan Khusus}

1. Mahasiswa mampu memahami Pengertian, tanda dan gejala, etiologi, klasifikasi, dan penatalaksanaan dan gangguan Harga Diri Rendah

2. Mahasiswa mampu melakukan pengkajian pada Ny. L dengan Gangguan konsep diri sensori: Harga Diri Rendah

3. Mahasiswa mampu menegakkan diagnosa keperawatan yang ada pada Ny. L dengan Gangguan konsep diri sensori: Harga Diri Rendah

4. Mahasiswa mampu menetapkan perencanaan keperawatan pada Ny. L dengan Gangguan konsep diri sensori: Harga Diri Rendah

5. Mahasiswa mampu melakukan implementasi keperawatan pada Ny. L dengan Gangguan konsep diri sensori: Harga Diri Rendah

6. Mahasiswa mampu mengevaluasi hasil asuhan keperawatan pada Ny. L dengan Gangguan konsep diri sensori: Harga Diri Rendah

7. Mahasiswa mampu mendokumentasikan hasil asuhan keperawatan pada Ny. L dengan Gangguan konsep diri sensori: Harga Diri Rendah 


\section{BAB 2 \\ TINJAUAN TEORITIS}

\subsection{Konsep Harga Diri Rendah}

\subsubsection{Defenisi}

Harga diri yang tinggi dikaitkan dengan kecemasan yang rendah, efektif dalam kelompok dan penerimaan orang lain terhadap dirinya, sedangkan masalah kesehatan dapat menyebabkan harga diri, sehingga harga diri dikaitkan dengan hubungan interperonal yang buruk dan beresiko terjadinya depresisehingga perasaan negatif mendasari hilangnya kepercayaan diri dan harga diri individu dan menggambarkan gangguan harga diri (Wandono, 2017). Harga diri rendah adalah disfungsi psikologis yang meluas-terlepas dari spesifiknya. Masalahnya, hampir semua pasien menyatakan bahwa mereka ingin memiliki harga diri yang lebih baik. Jika kita hanya mengurangi harga diri rendah, banyak masalah psikologis akan berkurang atau hilang secara substansial sepenuhnya (Pardede, Ariyo \& Purba, 2020).

Harga diri rendah merupakan kunci penting dimana yakin terhadap kemampuannya dalam melakukan suatu perilaku dalam memperoleh hasil yang diinginkan. Memiliki self-efficacy yang tinggi cenderung memiliki kenyakinan dan kemampuan untuk memperoleh suatu tujuan (Pardede, Ariyo \& Purba, 2020). Jika dihadapkan dengan yang sulit maka dibutuhkan kepercayaan dan kemampuan keluarga serta tindakan yang tepat untuk merawat anggota keluarga yang sakit (Pardede, Harjuliska, \& Ramadia, 2021).

\subsubsection{Klasifikasi}

klasifikasi harga diri rendah dibagi menjadi 2 jenis, yaitu :

1. Harga Diri Rendah Situsional adalah keadaan dimana individu yang sebelumnya memilki harga diri positif mengalami perasaan negatif mengenai diri dalam berespon, terhadap suatu kejadian (kehilangan, perubahan) 
2. Harga Diri Rendah Kronik adalah keadaan dimana individu mengalami evaluasi diri yang negatif mengenai diri atau kemampuan dalam waktu lama. (Pardede, Keliat, \& Yulia, 2020),

\subsubsection{Etiologi}

Berbagai faktor menunjang terjadinya perubahan dalam konsep diri seseorang menurut (Muhith, 2015)

\section{Faktor predisposisi}

Ada beberapa faktor predisposisi yang menyebabkan Harga Diri Rendah yaitu:

a. Perkembangan individu yang meliputi

1) Adanya penolakan dari orang tua, sehingga anak merasa tidak dicintai kemudian dampaknya anak gagal mencintai dirinya dan akan gagal pula untuk mencintaui orang lain.

2) Kurangnya pujian dan kurangnya pengakuan dari orang-orang tuanya atau orang tua yang penting/dekat individu yang bersangkutan.

3) Sikap orang tua protekting, anak merasa tidak berguna, orang tua atau orang terdekat sering mengkritik sering merevidasikan individu.

4) Anak menjadi frustasi, putus asa merasa tidak berguna dan merasa rendah diri.

b. Ideal diri

1) Individu selalu dituntut untuk berhasil.

2) Tidak mempunyai hak untuk gagal dan berbuat salah.

3) Anak dapat menghakimi dirinya sendiri dan hilangnya rasa percaya diri.

\section{Faktor presipitasi}

Faktor presipitasi atau stressor pencetus dari munculnya Harga Diri Rendah menurut (Pardede, Keliat, \& Yulia 2020), mungkin ditimbulkan dari sumber internal dan eksternal seperti: 
a. Gangguan fisik dan mental salah satu anggota keluarga sehingga keluarga merasa malu dan rendah diri.

b. Pengalaman traumatik berulang seperti penganiayaan seksual dan psikologis atau menyaksikan kejadian yang mengancam kehidupan, aniaya fisik, kecelakaan, bencana alam dalam perampokan. Respon terhadap trauma pada umunya akan mengubah arti trauma tersebut dan kopingnya adalah represi dan denial.

3. Perilaku

a. Dalam melakukan pengkajian, Perawat dapat memulai dengan mengobservasi penampilan Klien, misalnya kebersihan, dandanan, pakaian. Kemudian Perawat mendiskusikannya dengan Klien untuk mendapatkan pandangan Klien tentang gambaran dirinya.

b. Perilaku berhubungan dengan harga diri rendah. Harga diri yang Rendah merupakan masalah bagi banyak orang dan mengekspresikan melalui tingkat kecemasan yang sedang sampai berat. Umumnya disertai oleh evaluasi diri yang negatif membenci diri sendiri dan menolak diri sendiri (Pardede, Keliat, \& Wardani, 2013).

4. Rentang Respon

Tabel 2.1 Rentang Respon Harga Diri Rendah (Muhith, 2015)

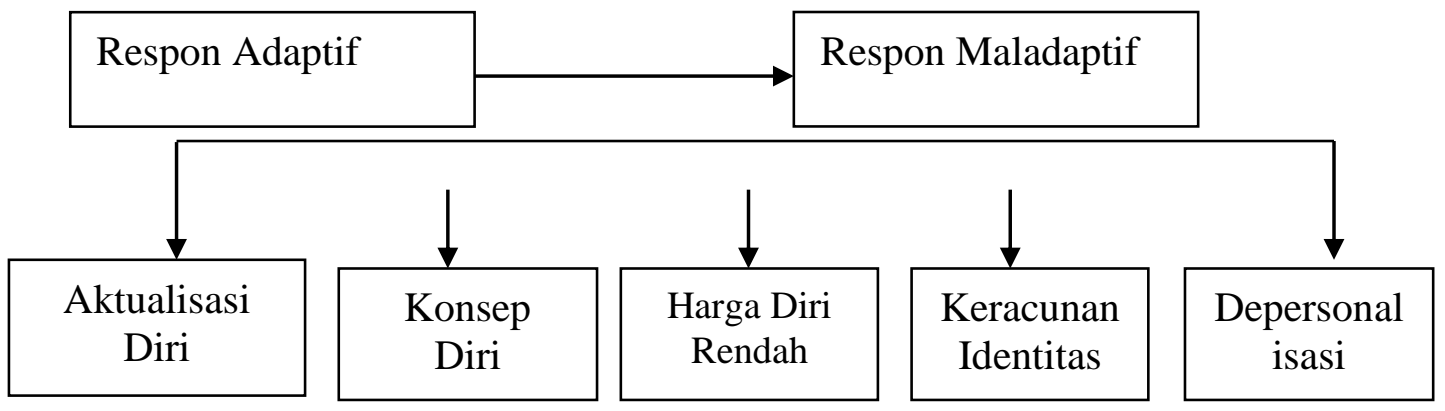




\section{Keterangang :}

a. Respon adaptif :

Aktualisasi diri dan konsep diri yang positif serta bersifat membangun (konstruksi) dalam usaha mengatasi stressor yang menyebabkan ketidakseimbangan dalam diri sendiri.

b. Respon maladaptif :

Aktualisasi diri dan konsep diri yang negatif serta bersifat merusak (destruktif) dalam usaha mengatasi stressor yang menyebabkan ketidakseimbangan dalam diri sendiri.

c. Aktualisasi diri :

Respon adaptif yang tertinggi karena individu dapat mengekspresikan kemampuan yang dimilikinya.

d. Konsep diri positif :

Individu dapat mengidentifikasi kemampuan dan kelemahannya secara jujur dan dalam menilai suatu masalah individu berpikir secara positif dan realistis.

e. Kekacauan identitas :

Suatu kegagalan individu untuk mengintegritasikan berbagai identifikasi masa kanak-kanak kedalam kepribadian psikososial dewasa yang harmonis.

f. Depersonalisasi :

Suatu perasaan yang tidak realistis dan keasingan dirinya dari lingkungan. Hal ini berhubungan dengan tingkat ansietas panik dan kegagalan dalam uji realitas. Individu mengalami kesulitan dalam membedakan diri sendiri dan orang lain dan tubuhnya sendiri terasa tidak nyata dan asing baginya.

5. Tanda dan Gejala

Berikut ini adalah tanda dan gejala harga diri rendah menurut (Keliat, 2018), yaitu :
a. Mengkritik diri sendiri
b. Perasaan tidak mampu
c. Apatis, ekspresi sedih, afek tumpul 
d. Menghindar dari orang lain (menyendiri)

e. Komunikasi kurang/tidak ada. Klien tidak tampak bercakapcakap dengan klien lain/perawat

f. Tidak ada kontak mata, klien sering menunduk, pandangan hidup yang pesimis

g. Berdiam diri di kamar/ klien kurang mobilitas atau penurunan produktivitas

h. Menolak berhubungan dengan orang lain, klien memutuskan percakapan atau pergi jika diajak bercakap-cakap dan penolakan terhadap kemampuan sendiri

i. Tidak/ jarang melakukan kegiatan sehari-hari

\section{Mekanisme Koping}

Mekanisme koping termasuk pertahanan koping jangka panjang pendek atau jangka panjang serta penggunaan mekanisme pertahanann ego untuk melindungi diri sendiri dalam menghadapi persepsi diri yang menyakitkan (Eko, 2014). Pertahanan tersebut mencakup berikut ini :

Jangka pendek :

a. Aktivitas yang memberikan pelarian semestara dari krisis identitas diri ( misalnya, konser musik, bekerja keras, menonton tv secara obsesif)

b. Aktivitas yang memberikan identitas pengganti semestara (misalnya, ikut serta dalam klub sosial, agama, politik, kelompok, gerakan, atau geng)

c. Aktivitas yang sementara menguatkan atau meningkatkan perasaan diri yang tidak menentu (misalnya, olahraga yang kompetitif, prestasi akademik, kontes untuk mendapatkan popularitas)

Menurut Pardede (2019), pertahanan jangka panjang mencakup berikut ini : 
1) Penutupan identitas : adopsi identitas prematur yang diinginkan oleh orang terdekat tanpa memerhatikan keinginan,aspirasi,atau potensi diri individu

2) Identitas negatif : asumsi identitas yang tidak sesuai dengan nilai dan harapan yang diterima masyarakat.

3) Mekanisme pertahanan ego termasuk penggunaan fantasi, disosiasi, isolasi, proyeksi, pengalihan (displacement, berbalik marah terhadap diri sendiri, dan amuk).

\subsubsection{Penatalaksanaan}

Terapi pada gangguan jiwa skizofrenia dewasa ini sudah dikembangkan sehingga penderita tidak mengalami diskriminasi bahkan metodenya lebih manusiawi dari pada masa sebelumnya (Pardede, Keliat, \& Yulia, 2015). Terapi yang dimaksud meliputi :

\section{Psikofarmaka}

Berbagai jenis obat psikofarmaka yang beredar dipasaran yang hanya diperoleh dengan resep dokter, dapat dibagi dalam 2 golongan yaitu golongan generasi pertama (typical) dan golongan kedua (atypical). Obat yang termasuk golongan generasi pertama misalnya chlorpromazine HCL (psikotropik untuk menstabilkan senyawa otak), dan Haloperidol (mengobati kondisi gugup). Obat yang termasuk generasi kedua misalnya, Risperidone (untuk ansietas), Aripiprazole (untuk antipsikotik).

\section{Psikoterapi}

Terapi kerja baik sekali untuk mendorong penderita bergaul lagi dengan orang lain, penderita lain, perawat dan dokter, maksudnya supaya ia tidak mengasingkan diri lagi karena bila ia menarik diri ia dapat membentuk kebiasaan yang kurang baik. Dianjurkan untuk mengadakan permainan atau latihan bersama (Rokhimma \& Rahayu, 2020). 


\subsection{Konsep Asuhan Keperawatan}

Adapun konsep asuhan keperawatan harga diri rendah menurut (Keliat, 2015), adalah sebagai berikut :

\subsubsection{Pengkajian}

a. Identifikasi klien

b. Perawat yang merawat klien melakukan perkenalan dan kontrak dengan klien tentang: Nama klien, panggilan klien, Nama perawat, tujuan, waktu pertemuan, topik pembicaraan.

c. Keluhan utama / alasan masuk

1) Tanyakan pada keluarga / klien hal yang menyebabkan klien dan keluarga datang ke Rumah Sakit, yang telah dilakukan keluarga untuk mengatasi masalah dan perkembangan yang dicapai.

2) Tanyakan pada klien / keluarga, apakah klien pernah mengalami gangguan jiwa pada masa lalu, pernah melakukan, mengalami, penganiayaan fisik, seksual, penolakan dari lingkungan, kekerasan dalam keluarga dan tindakan kriminal.

d. Psikologis

Keluarga, pengasuh dan lingkungan klien sangat mempengaruhi respon psikologis dari klien.

e. Biologis

Gangguan perkembangan dan fungsi otak atau SSP, pertumbuhan dan perkembangan individu pada prenatal, neonatus dan anak-anak.

f. Sosial Budaya

Seperti kemiskinan, konflik sosial budaya (peperangan, kerusuhan, kerawanan), kehidupan yang terisolasi serta stress yang menumpuk. 
g. Aspek fisik / biologis

Mengukur dan mengobservasi tanda-tanda vital: TD, nadi, suhu, pernafasan. Ukur tinggi badan dan berat badan, kalau perlu kaji fungsi organ kalau ada keluhan.

h. Aspek psikososial

1) Membuat genogram yang memuat paling sedikit tiga generasi yang dapat menggambarkan hubungan klien dan keluarga, masalah yang terkait dengan komunikasi, pengambilan keputusan dan pola asuh.

2) Konsep diri

a) Citra tubuh: mengenai persepsi klien terhadap tubuhnya, bagian yang disukai dan tidak disukai.

b) Identitas diri: status dan posisi klien sebelum dirawat, kepuasan klien terhadap status dan posisinya dan kepuasan klien sebagai laki-laki / perempuan.

c) Peran: tugas yang diemban dalam keluarga / kelompok dan masyarakat dan kemampuan klien dalam melaksanakan tugas tersebut.

d) Ideal diri: harapan terhadap tubuh, posisi, status, tugas, lingkungan dan penyakitnya.

e) Harga diri: hubungan klien dengan orang lain, penilaian dan penghargaan orang lain terhadap dirinya, biasanya terjadi pengungkapan kekecewaan terhadap dirinya sebagai wujud harga diri rendah.

3) Hubungan sosial dengan orang lain yang terdekat dalam kehidupan, kelompok yang diikuti dalam masyarakat.

4) Spiritual, mengenai nilai dan keyakinan dan kegiatan ibadah.

i. Status mental

Nilai penampilan klien rapi atau tidak, amati pembicaraan klien, aktivitas motorik klien, alam perasaan klien (sedih, takut, khawatir), afek klien, interaksi selama wawancara, persepsi 
klien, proses pikir, isi pikir, tingkat kesadaran, memori, tingkat konsentasi dan berhitung, kemampuan penilaian dan daya tilik diri.

\subsubsection{Implementasi}

Menurut Pardede, Keliat, \& Yulia (2015), implementasi disesuaikan dengan rencana tindakan keperawatan. Pada situasi nyata sering pelaksanaan jauh berbeda dengan rencana, hal ini terjadi karena perawat belum terbiasa menggunakan rencana tertulis dalam melaksanakan tindakan keperawatan. Sebelum melaksanakan tindakan keperawatan yang sudah direncanakan, perawat perlu memvalidasi dengan singkat apakah rencana tindakan masih sesuai dan dibutuhkan klien sesuai dengan kondisinya (here and now). Perawat juga menilai diri sendiri, apakah kemampuan interpersonal, intelektual, tekhnikal sesuai dengan tindakan yang akan dilaksanakan, dinilai kembali apakah aman bagi klien. Setelah semuanya tidak ada hambatan maka tindakan keperawatan boleh dilaksanakan (Rokhimma \& Rahayu, 2020).

\subsubsection{Evaluasi}

Kemampuan yang diharapkan dari pasien menurut (Keliat, 2016), yaitu:

1. Pasien dapat mengungkapkan kemampuan dan aspek positif yang dimliki

2. Pasien dapat menilai kemampuan yang dapat dikerjakan

3. Pasien dapat melatih kemampuan yang dapat dikerjakan

4. Pasien dapat membuat jadwal kegiatan harian

5. Pasien dapat melakukan kegiatan sesuai jadwal kegaiatan harian 


\section{BAB 3 \\ TINJAUAN KASUS}

\subsection{Identitas Pasien}

$\begin{array}{lll}\text { Inisial } & : & \text { Ny.L } \\ \text { Jenis kelamin } & : & \text { Perempuan } \\ \text { Umur } & : & 56 \text { Tahun } \\ \text { Agama } & : & \text { Budha } \\ \text { Status } & : & \text { Menikah } \\ \text { Tanggal pengkajian } & : & \text { 02-27 Maret 2021 } \\ \text { Informent } & : & \text { Pengawas yayasan dan pasien }\end{array}$

\subsection{Alasan Masuk Yayasan Pemenang Jiwa}

Alasan pasien masuk ke yayasan pemenangan jiwa adalah pasien berbicara dan tertawa sendiri, pemilik Yayasan Pemenangan Jiwa bertemu dengan si pasien di jalanan dalam keadaan si pasien sedang memakan sisa- sisa makanan dari pembuangan sampah, dan si pasien tampak kelihatan sangatlah kotor dan bau. Berdasarkan informasi yang diperoleh dari staf pegawai yayasan, pasien ketika pertama kali masuk yayasan sempat marah-marah kepada lingkungan sekitar, dan setibanya di yayasan ketika pasien disuruh mandi pasien marah-marah.

\subsection{Faktor Predisposisi}

Pasien sebelumnya belum pernah mengalami gangguan jiwa, yang mengakibatkan pasien menjadi gangguan jiwa karena suami Ny.L selingkuh dengan wanita lain. Itu yang menyebabkan Ny.L marah-marah kepada keluarga, menarik diri, Ny. L merasa dirinya tidak berguna lagi sehingga ia lebih menutup diri

Masalah keperawatan yang muncul : Harga Diri Rendah Kronis

\subsection{Fisik}

Pasien tidak memiliki keluhan fisik, saat dilakukan pemeriksaan tanda-tanda vital, didapatkan hasil TD : 120/80 mmHg ; $\mathrm{N}: 75 x / 1$; S : 37 ${ }^{\circ} \mathrm{C} ; \mathrm{P}: 20 \mathrm{x} / \mathrm{i}$. Pasien memiliki tinggi badan $145 \mathrm{~cm}$ dan berat badan $65 \mathrm{Kg}$. 


\subsection{Psikososial}

\subsubsection{Genogram}

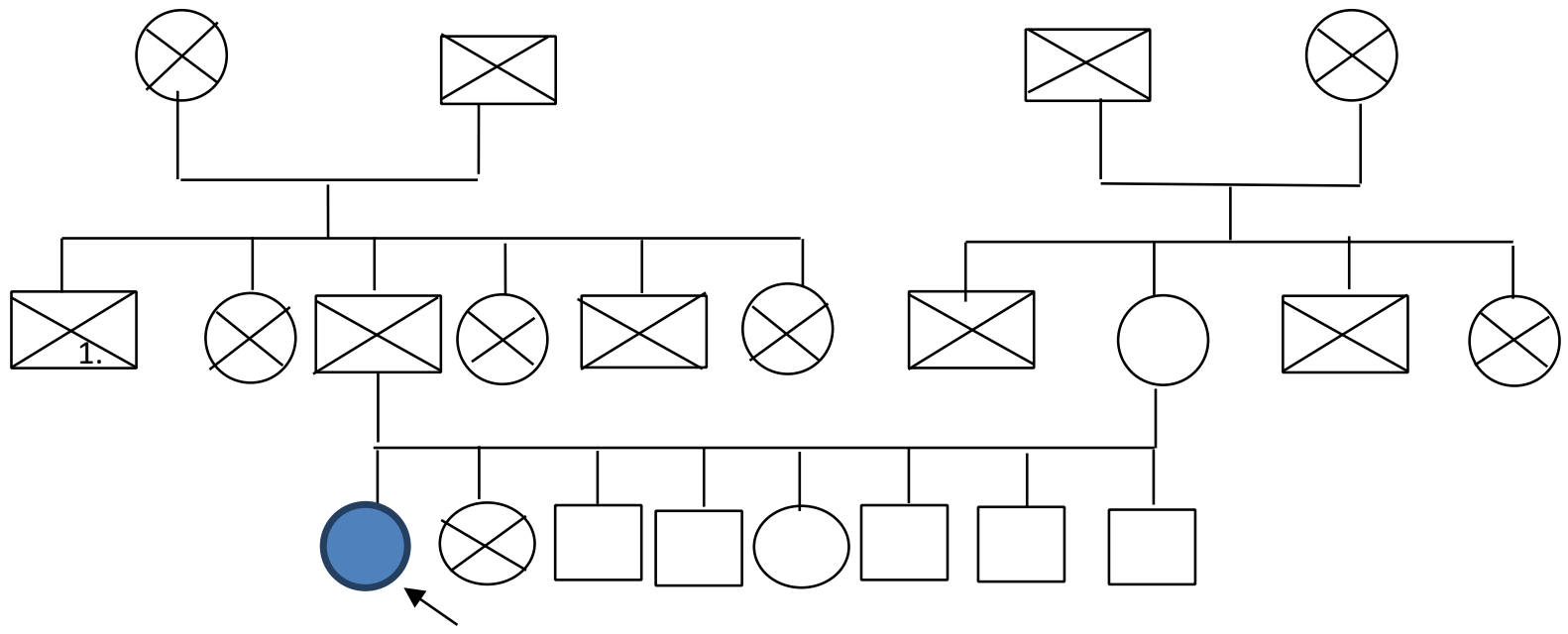

Penjelasan :

Pasien anak pertama dari 8 bersaudara, pasien berinisial Ny.L, pasien memiliki ibu sedangkan ayah pasien sudah meninggal dunia dan saat usia pasien 10 tahun. Ny. L belum menikah. Keterangan :

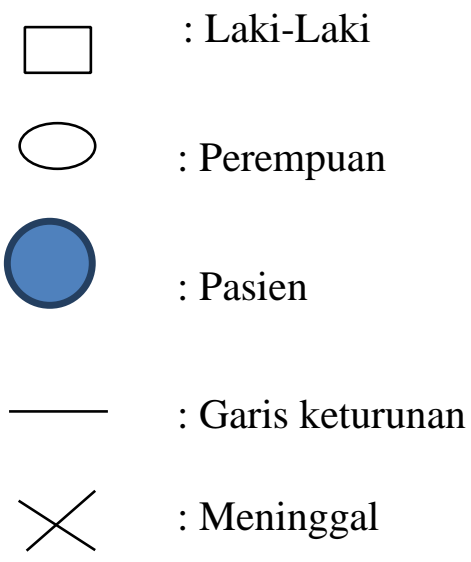

\subsubsection{Konsep Diri}

1. Gambaran diri : Pasien menyukai seluruh tubuhnya dan tidak ada yang cacat

2. Identitas : Pasien anak ke 1 dari 8 bersaudara, Pasien lulusan SMA yang saat ini tidak memiliki pekerjaan

3. Peran : Pasien berperan sebagai istri dan ibu dari anakanaknya, tetapi tidak lagi selama gangguan jiwa

4. Ideal diri : Pasien ingin cepat sembuh 
5. Harga diri : Pasien merasa tidak berarti lagi dalam keluarganya

6. Masalah Keperawatan : Harga diri rendah

\subsubsection{Hubungan Sosial}

1. Orang yang berarti : orang yang berarti saat ini dalam kehidupan Pasien adalah pemilik yayasan serta staf pegawai yayasan dikarenakan mereka yang menjaga dan merawat pasien tersebut

2. Peran sertadalam kegiatankelompok/masyarakat: Pasien bersifat apatis, ketika tidak ada yang mengarahkannya untuk melakukan suatu kegiatan.Pasien selalu mengikuti kegiatan kelompok di yayasan seperti beribadah, bergotong royong (memberikan halaman rumah, membakar sampah). Akan tetapi harus selalu diarahkan terlebih dahulu.

3. Hambatan dalam berbuhungan dengan orang Lain : Pasien hanya berbicara seperlunya saja. Ketika di tanya, pasien hanya sebatas menjawab pertanyaan kita, lalu kebanyakan diam Masalah Keperawatan : Harga Diri Rendah

\subsubsection{Spiritual}

1. Nilai dan Keyakinan : Pasien beragama Budha

2. Kegiatan Ibadah : Pasien selalu mengikuti ibadah yang dilakukan di yayasan

\subsubsection{Status Mental}

1. Penampilan

Pasien berpenampilan bersih, dan rapi

3. Pembicaraan

Pasien tidak mampu menjawab pertanyaan dengan jelas dan tidak dapat cepat memahami pertanyaan yang diberikan

4. Aktivitas Motorik

Pasien terlihat sedikit gelisah 
5. Suasana perasaan

Pasien merasa dibuang oleh keluarganya dan merasa minder dengan orang lain karena di rawat diyayasan pemenang jiwa Masalah keperawatan : Harga Diri Rendah

6. Afek

Afek pasien labil, dan sering menunduk

Masalah keperawatan :Isolasi sosial

7. Interaksi selama wawancara

Pasien kooperatif, tidak ada kontak mata pada lawan bicara, sering menunduk dan tidak banyak bicara.

8. Persepsi

pasien merasa tidak pernah dihargai

9. Proses Pikir

Pasien tidak mampu menjawab apa yang ditanya dengan baik.

10. Isi piker

Pasien tidak dapat mengontrol isi pikirnya, pasien mengalami gangguan isi pikir akibat epilepsi dan tidak ada waham.

11. Tingkat kesadaran

Pasien mengalami gangguan orientasi, pasien mengenali waktu, orang dan tempat sesaat.

12. Memori

Pasien tidak mampu menceritakan kejadian di masa lalu

13. Tingkat konsentrasi berhitung

Pasien mampu berkonsentrasi dalam perhitungan sederhana tanpa bantuan orang lain.

14. Kemampuan penilaian

Pasien dapat membedakan hal yang baik dan yang buruk.

15. Daya tilik diri

Pasien tidak mengingkari penyakit yang diderita, pasien mengetahui bahwa dia sering marah. 


\subsection{Mekanisme Koping}

Pasien mengalami mekanisme koping adaptif yaitu pasien dapat berbicara baik dengan orang lain.

\subsection{Masalah Psikososial dan Lingkungan}

Pasien mengatakan sulit berteman dengan orang lain karena pasien lebih banyak diam, pasien sangat sulit untuk memulai pembicaraan dengan orang lain.

\subsection{Pengetahuan Kurang Tentang Gangguan Jiwa}

Pasien tidak mengetahui tentang penyakit gangguan jiwa dan pasien tidak tahu obat apa yang diminum nya setiap hari yang diberikan oleh staf pegawai yayasan.

\subsection{Analisa Data}

\begin{tabular}{|c|c|c|}
\hline No. & Identifikasi Data & Masalah Keperawatan \\
\hline 1. & $\begin{aligned} & \text { DS : } \\
&- \text { Klien merasa tidak dihargai dan } \\
& \text { klien merasa tidak berguna } \\
&- \text { Klien merasa minder dan malu } \\
& \text { karena suaminya menyelingkuhiya } \\
& \text { DO : } \\
&- \text { Klien tampak sedih, suara menjadi } \\
& \text { pelan, kontak mata kurang } \\
&\end{aligned}$ & $\begin{array}{l}\text { Gangguan Konsep Diri : } \\
\text { Harga diri rendah kronis }\end{array}$ \\
\hline 2. & $\begin{array}{l}\text { DS : } \\
\text { Pasien mengatakan pernah menerima } \\
\text { tindak kekerasan dari suami } \\
\text { DO : } \\
\quad \text { - Pasien tampak tidak dapat } \\
\quad \begin{array}{l}\text { memandang orang lain dan sering } \\
\text { menunduk }\end{array}\end{array}$ & Isolasi Sosial \\
\hline 3. & $\begin{aligned} \text { DS : } & \\
- & \text { Klien mengatakan sering } \\
& \text { mendengar suara - suara yang } \\
& \text { memanggil namanya namun } \\
& \text { orangnya tidak terlihat } \\
- & \text { Klien merasa takut dan gelisah jika } \\
& \text { mendengar suara itu muncul } \\
- & \text { Klien sering mendengar suara itu }\end{aligned}$ & $\begin{array}{l}\text { Gangguan Persepsi } \\
\text { Sensori : Halusinasi } \\
\text { Pendengaran }\end{array}$ \\
\hline
\end{tabular}




\begin{tabular}{|r|l|l|}
\hline DO : & jika klien sendirian \\
- & Klien menutup telinganya saat \\
& suara itu datang memanggil \\
namanya & Klien berbicara ngawur dan senyum \\
& - senyum sendiri
\end{tabular} \mid

\subsection{Pohon masalah}

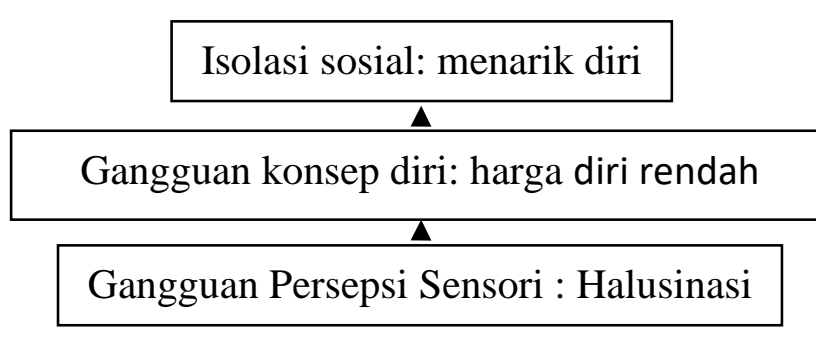

Diagnosa Keperawatan Prioritas :

Gangguan konsep diri: harga diri rendah

\subsection{Intervensi Keperawatan}

\begin{tabular}{|c|c|c|c|}
\hline $\begin{array}{c}\text { Diagnosa } \\
\text { Keperawatan }\end{array}$ & Tujuan & Kriteria Hasil & Intervensi \\
\hline $\begin{array}{l}\text { Gangguan } \\
\text { konsep diri : } \\
\text { harga diri } \\
\text { rendah }\end{array}$ & $\begin{array}{c}\text { Klien } \\
\text { dapat } \\
\text { membina } \\
\text { hubungan } \\
\text { saling } \\
\text { percaya }\end{array}$ & $\begin{array}{l}\text { 1. Klien mampu } \\
\text { mengidentifikasi } \\
\text { kemampuan dan } \\
\text { aspek positif yang } \\
\text { dimiliki } \\
\text { 2. Klien mampu } \\
\text { menilai } \\
\text { kemampuan yang } \\
\text { dapat digunakan } \\
\text { 3. } \begin{array}{l}\text { Klien mampu } \\
\text { menetapkan/mem }\end{array} \\
\text { ilih kegiatan } \\
\text { sesuai } \\
\text { kemampuan } \\
\text { 4. Klien mampu } \\
\text { melatih kegiatan } \\
\text { sesuai } \\
\text { kemampuan yang } \\
\text { dipilih } 1 \\
\text { 5. Klien mampu } \\
\text { melatih kegiatan } \\
\text { sesuai } \\
\text { kemampuan yang }\end{array}$ & $\begin{array}{l}\text { SP } 1: \text { Mengidentifikasi } \\
\text { kemampuan dan aspek positif } \\
\text { yang dimiliki } \\
\text { SP 2: } \\
\checkmark \quad \text { Menilai kemampuan } \\
\text { yang dapat digunakan } \\
\checkmark \text { Menetapkan/memilih } \\
\text { kegiatan sesuai } \\
\quad \text { kemampuan } \\
\checkmark \text { Melatih kegiatan sesuai } \\
\text { kemampuan yang dipilih } \\
\text { SP 3: Melatih kegiatan sesuai } \\
\text { kemampuan yang dipilih 2 } \\
\text { SP 4: Melatih kegiatan sesuai } \\
\text { kemampuan yang dipilih 3 }\end{array}$ \\
\hline
\end{tabular}




\begin{tabular}{|c|c|c|c|}
\hline & & $\begin{array}{l}\text { dipilih } 2 \\
\text { 1. Klien mampu } \\
\text { melatih kegiatan } \\
\text { sesuai } \\
\text { kemampuan yang } \\
\text { dipilih 3 } \\
\end{array}$ & \\
\hline $\begin{array}{l}\text { Menarik diri : } \\
\text { Isolasi Sosial }\end{array}$ & $\begin{array}{l}\text { Klien } \\
\text { dapat } \\
\text { membina } \\
\text { hubungan } \\
\text { saling } \\
\text { percaya }\end{array}$ & $\begin{array}{l}\text { 2. Klien mampu } \\
\text { memahami } \\
\text { penjelasan } \\
\text { keuntungan dan } \\
\text { keruguan } \\
\text { memiliki teman } \\
\text { 3. Klien mampu } \\
\text { melakukan } \\
\text { perkenalan } \\
\text { dengan dua orang } \\
\text { atau lebih } \\
\text { 4. Klien mampu } \\
\text { bercakap-cakap } \\
\text { sambal } \\
\text { melakukan } \\
\text { kegiatan harian } \\
\text { 6. Klien mampu } \\
\text { berbicara social } \\
\text { meminta sesuatu } \\
\text { berbelanja dan } \\
\text { sebagainya. }\end{array}$ & $\begin{array}{l}\text { SP1: } \\
\text { Menjelasan keuntungan dan } \\
\text { keruguan memiliki teman } \\
\text { SP 2: } \\
\text { Melatih klien berkenalan dengan } \\
\text { dua orang atau lebih } \\
\text { SP 3: } \\
\text { Melatih bercakap-cakap sambal } \\
\text { melakukan kegiatan harian } \\
\text { SP 4: } \\
\text { Melatih berbicara social } \\
\text { meminta sesuatu berbelanja dan } \\
\text { sebagainya. }\end{array}$ \\
\hline $\begin{array}{l}\text { Gangguan } \\
\text { Persepsi } \\
\text { Sensori } \\
\text { Halusinasi }\end{array}$ & $\begin{array}{l}\text { Klien } \\
\text { dapat } \\
\text { mebina } \\
\text { hubungan } \\
\text { saling } \\
\text { percaya }\end{array}$ & $\begin{array}{l}\text { 1. Klien mampu } \\
\text { mengenal } \\
\text { halusinasinya } \\
\text { 2. Klien mampu } \\
\text { Mengontrol } \\
\text { halusinasi dengan } \\
\text { cara menghardik } \\
\text { 3. Klien mampu } \\
\text { mengontrol } \\
\text { halusinasi dengan } \\
\text { makan obat teratur } \\
\text { 4. Klien mampu } \\
\text { mengontrol } \\
\text { halusinasi dengan } \\
\text { bercakap-cakap } \\
\text { dengan orang lain } \\
\text { 5. Klien mampu } \\
\text { mengontrol } \\
\text { halusinasi dengan } \\
\text { melakukan kegiatan } \\
\text { terjadwal. }\end{array}$ & $\begin{array}{rlr}\text { Sp } 1 \text { : } & \\
& \checkmark & \text { Mengidentifikasi isi, } \\
& \text { frekuensi, waktu terjadi, } \\
& \text { situasi pencetus, }\end{array}$ \\
\hline
\end{tabular}




\subsection{Implementasi dan Evaluasi}

\begin{tabular}{|c|c|c|}
\hline $\begin{array}{c}\text { Hari / } \\
\text { Tgl }\end{array}$ & Implementasi & Evaluasi \\
\hline $\begin{array}{l}\text { Jumat, } \\
19 \\
\text { maret } \\
2021 . \\
11.30 \\
\text { Wib. }\end{array}$ & $\begin{array}{l}\text { Data } \\
\text { - Klien tampak murung } \\
\text { - Berbicara hanya ketika ditanya } \\
\text { - Nada bicara pelan } \\
\text { Diagnosa Keperawatan } \\
\text { Gangguan konsep diri : Harga Diri } \\
\text { Rendah } \\
\text { Tindakan Keperawatan } \\
\text { Sp1 } \\
\text { Mengidentifikasi kemampuan dan } \\
\text { aspek positif yang dimiliki pasien } \\
\text { RTL } \\
\text { Sp } 2 \text { : - menilai kemampuan yang } \\
\text { dapat digunakan } \\
\text { - Menetapkan/memilih kegiatan } \\
\quad \text { sesuai kemampuan } \\
\text { - Melatih kegiatan sesuai } \\
\text { Spemampuan yang dipilih } 1 \\
\quad \text { : Melatih kegiatan sesuai } \\
\text { kemampuan yang dipilih } 2\end{array}$ & $\begin{array}{l}\text { S : Senang : } \\
\quad \text { Pasien mampu } \\
\quad \text { mengenali } \\
\quad \text { Mengidentifikasi } \\
\quad \text { kemampuan dan } \\
\quad \text { aspek positif yang } \\
\quad \text { dimiliki pasien } \\
\text { A : harga diri rendah (+) } \\
\text { P : Latihan mengidentifikasi } \\
\text { kemampuan dan aspek positif } \\
\text { yang dimiliki pasien harga } \\
\text { diri rendah 3x/hari }\end{array}$ \\
\hline $\begin{array}{l}\text { Selasa, } \\
22 \\
\text { maret } \\
2021 . \\
11.30 \\
\text { Wib }\end{array}$ & $\begin{array}{l}\text { Data } \\
\text { Tanda dan gejala : } \\
\text { - Klien tampak murung } \\
\text { - Berbicara hanya ketika ditanya } \\
\text { - Nada bicara pelan } \\
\text { Diagnosa keperawatan } \\
\text {-Harga diri rendah } \\
\text { Tindakan keperawatan } \\
\text { Sp2 : - menilai kemampuan yang dapat } \\
\quad \text { digunakan } \\
\text { - Menetapkan/memilih kegiatan } \\
\quad \text { sesuai kemampuan } \\
\text { - Melatih kegiatan sesuai } \\
\quad \text { kemampuan yang dipilih } 1 \\
\text { Sp3 : Melatih kegiatan sesuai } \\
\text { kemampuan yang dipilih } 2\end{array}$ & 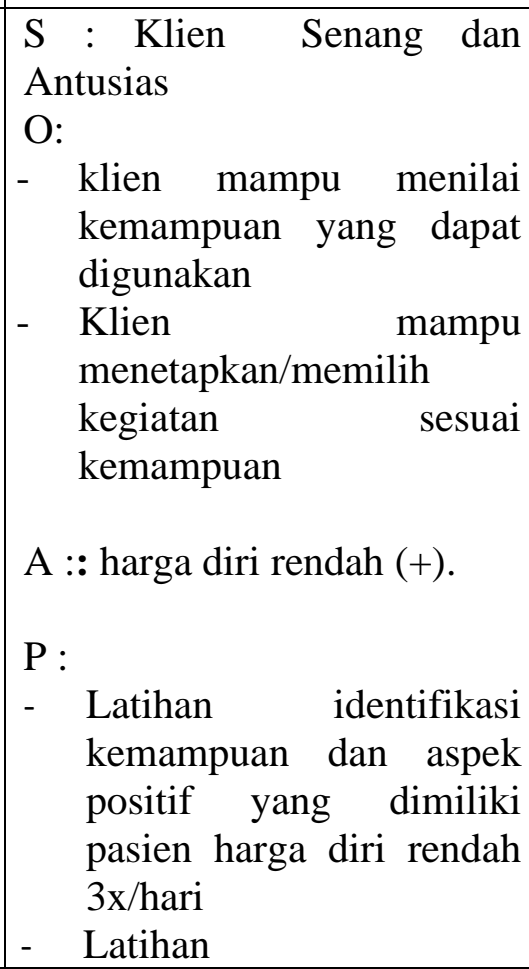 \\
\hline
\end{tabular}




\begin{tabular}{|c|c|c|}
\hline & $\begin{array}{ll}\text { RTL : } & \\
\quad- & \text { Sp4 : melatih kegiatan sesuai } \\
& \text { kemampuan yang dipilih } 3\end{array}$ & \begin{tabular}{l}
\multicolumn{3}{l}{ menetapkan/memilih } \\
kegiatan sesuai \\
kemampuan 3x/ hari \\
- Latihan kegiatan sesuai \\
kemampuan yang dipilih \\
$13 \mathrm{x} /$ hari \\
- Latihan kegiatan sesuai \\
kemampuan yang dipilih \\
$23 \mathrm{x} /$ hari. \\
Latihan kegiatan sesuai \\
kemampuan yang dipilih \\
$33 \mathrm{x} /$ hari
\end{tabular} \\
\hline $\begin{array}{l}\text { Selasa, } \\
22 \\
\text { maret } \\
2021 . \\
11.30 \\
\text { Wib }\end{array}$ & $\begin{array}{l}\text { Data } \\
\text { Tanda dan gejala : } \\
\quad \text { - Klien tampak murung } \\
\text { - Berbicara hanya ketika ditanya } \\
\text { - Nada bicara pelan } \\
\text { Diagnosa keperawatan } \\
\text {-Harga diri rendah } \\
\text { Tindakan keperawatan } \\
\text { Sp4 : melatih kegiatan sesuai } \\
\text { kemampuan yang dipilih } 3\end{array}$ & 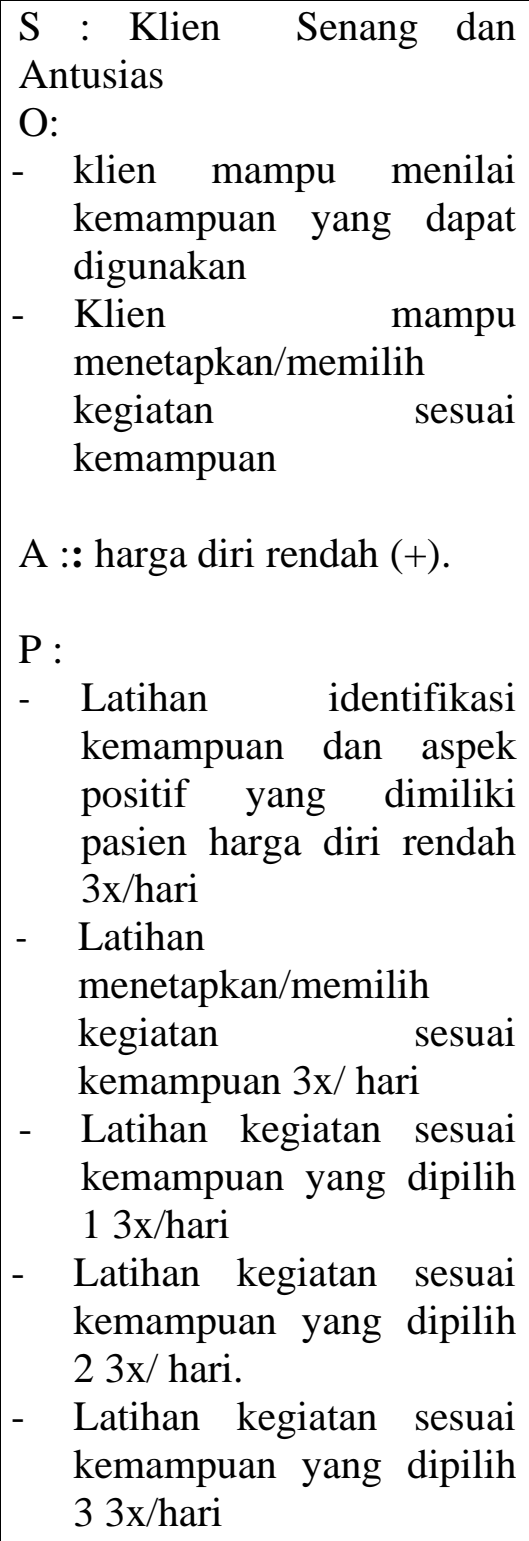 \\
\hline
\end{tabular}




\begin{tabular}{|c|c|c|}
\hline $\begin{array}{l}\text { Selasa, } \\
22 \\
\text { maret } \\
2021 . \\
11.30 \\
\text { Wib }\end{array}$ & $\begin{array}{l}\text { Data } \\
\text { Tanda dan gejala : } \\
\text { - Klien tampak murung } \\
\text { - Berbicara hanya ketika ditanya } \\
\text { - Nada bicara pelan } \\
\text { Diagnosa keperawatan } \\
\text {-Harga diri rendah } \\
\text { Tindakan keperawatan } \\
\text { Sp4 : melatih kegiatan sesuai } \\
\text { kemampuan yang dipilih } 3\end{array}$ & $\begin{array}{l}\text { S : Klien Senang dan } \\
\text { Antusias } \\
\text { O: } \\
\text { - klien mampu menilai } \\
\text { kemampuan yang dapat } \\
\text { digunakan } \\
\text { - Klien mampu } \\
\text { menetapkan/memilih } \\
\text { kegiatan sesuai } \\
\text { kemampuan } \\
\text { A :: harga diri rendah (+). } \\
\text { P : } \\
\text { Latihan identifikasi } \\
\text { kemampuan dan aspek } \\
\text { positif yang dimiliki } \\
\text { pasien harga diri rendah } \\
\text { 3x/hari } \\
\text { Latihan } \\
\text { menetapkan/memilih } \\
\text { kegiatan sesuai } \\
\text { kemampuan 3x/ hari } \\
\text { Latihan kegiatan sesuai } \\
\text { kemampuan yang dipilih } \\
\text { 1 3x/hari } \\
\text { Latihan kegiatan sesuai } \\
\text { kemampuan yang dipilih } \\
\text { 2 3x/ hari. } \\
\text { Latihan kegiatan sesuai } \\
\text { kemampuan yang dipilih } \\
\text { 3 3x/hari }\end{array}$ \\
\hline $\begin{array}{l}\text { Kamis } \\
11 \\
\text { maret } \\
2021 . \\
11.30 \\
\text { WIB. }\end{array}$ & $\begin{array}{l}\text { Data : } \\
\quad \text { Tanda dan gejala : pasien selalu } \\
\text { menunduk dan tidak mampu } \\
\text { menjawab pertanyaan yang } \\
\quad \text { diberikan dengan lancar } \\
\text { Diagnosa Keperawatan Isolasi Sosial } \\
\text { Isolasi Sosial } \\
\text { Tindakan keperawatan: } \\
\text { SP 2: } \\
\text { Melatih klien berkenalan dengan dua } \\
\text { orang atau lebih } \\
\text { SP 3: }\end{array}$ & $\begin{array}{l}\text { A : Isolasi Sosial (+) } \\
\text { P : } \\
\text { - } \quad \begin{array}{l}\text { Latihan berkenalan } \\
\\
\text { dengan dua orang } \\
\\
\text { atau lebih 1x sehari }\end{array}\end{array}$ \\
\hline
\end{tabular}




\begin{tabular}{|c|c|c|}
\hline & $\begin{array}{l}\text { Melatih bercakap-cakap sambal } \\
\text { melakukan kegiatan harian: } \\
\text { RTL: } \\
\text { SP 4: } \\
\text { Melatih kegiatan sesuai kemampuan } \\
\text { yang dipilih } 3\end{array}$ & $\begin{array}{l}\text { Latihan komunikasi } \\
\text { secara verbal : } \\
\text { asertif/bicara baik- } \\
\text { baik 3x/ hari. }\end{array}$ \\
\hline $\begin{array}{l}\text { Selasa, } \\
16 \\
\text { maret } \\
2021 . \\
10.30 \\
\text { Wib. }\end{array}$ & $\begin{array}{l}\text { Data : } \\
\quad \text { Tanda dan gejala : pasien selalu } \\
\text { menunduk dan tidak mampu } \\
\text { menjawab pertanyaan yang } \\
\text { diberikan dengan lancar } \\
\text { Diagnosa Keperawatan Isolasi Sosial } \\
\text { Isolasi Sosial } \\
\text { Tindakan keperawatan: } \\
\text { SP 3: } \\
\text { Melatih bercakap-cakap sambal } \\
\text { melakukan kegiatan harian: } \\
\text { SP 4: } \\
\text { Melatih kegiatan sesuai kemampuan } \\
\text { yang dipilih } 3 \\
\text { RTL: } \\
\text { Pemberian Sp Harga Diri Rendah } \\
\text { Sp1 } \\
\text { Mengidentifikasi kemampuan dan } \\
\text { aspek positif yang dimiliki pasien }\end{array}$ & $\begin{array}{l}\text { - Latihan berkenalan } \\
\text { dengan dua orang } \\
\text { atau lebih } 1 \mathrm{x} \text { sehari } \\
\text { - Latihan komunikasi } \\
\text { secara verbal : } \\
\text { asertif/bicara baik- } \\
\text { baik } 3 \mathrm{x} / \text { hari. }\end{array}$ \\
\hline $\begin{array}{l}\text { Selasa } \\
9 \text { mare } \\
2021 . \\
10.30 \\
\text { Wib. }\end{array}$ & $\begin{array}{l}\text { Data } \\
\text { Tanda dan gejala: } \\
\text { klien mengeluh merasa terikat bagian } \\
\text { hidungnya dan sulit menelan } \\
\text { Diagnosa Keperawatan } \\
\text { Gangguan persepsi sensori : halusinasi } \\
\text { perabaan } \\
\text { Tindakan Keperawatan } \\
\text { Sp1 halusinasi } \\
\text { - Melatih pasien mengidentifikasi } \\
\quad \text { halusinasinya; isi, frekuensi, } \\
\text { watu terjadi, sruasi pencetus, } \\
\text { perasaan dan respon halusinasi }\end{array}$ & $\begin{array}{l}\text { S : Senang } \\
\text { O : } \\
\text { - } \text { Pasien mampu mengenali } \\
\text { halusinasi yang dialami } \\
\text { nya; isi, frekuensi, watu } \\
\text { terjadi, sruasi } \\
\text { pencetus,perasaan, respon } \\
\text { dengan mandiri } \\
\text { - } \\
\text { Pasien mampu } \\
\text { Mengontrol halusinasinya } \\
\text { dengan cara menghardik } \\
\text { dengan bantuan } \\
\text { A : } \\
\text { P : }\end{array}$ \\
\hline
\end{tabular}




\begin{tabular}{|c|c|c|}
\hline & $\begin{array}{l}\text { - Mengontrol halusinasi dengan } \\
\text { cara menghardik } \\
\text { RTL } \\
\text { Sp2 : mengontrol halusinasi dengan } \\
\text { cara minum obat } \\
\text { Sp3 : mengontrol halusinasi dengan } \\
\text { cara bercakap - cakap }\end{array}$ & $\begin{array}{l}\text { - } \text { Latihan mengidentifikasi } \\
\text { halusinasinya; isi, } \\
\text { frekuensi, watu terjadi, } \\
\text { sruasi pencetus, perasaan } \\
\text { dan respon halusinasi } \\
3 \mathrm{x} / \text { hari } \\
\text { Latihan menghardik } \\
\text { halusinasi } 3 \mathrm{x} / \text { hari }\end{array}$ \\
\hline $\begin{array}{l}\text { Kamis, } \\
11 \\
\text { maret } \\
2021 . \\
11.30 \\
\text { WIB. }\end{array}$ & $\begin{array}{l}\text { Data } \\
\text { Tanda dan gejala : Tanda dan gejala } \\
\text { :klien mengeluh merasa terikat } \\
\text { bagian hidungnya dan sulit menelan } \\
\text { Diagnosa keperawatan } \\
\text { Gangguan persepsi sensori : Halusinasi } \\
\text { perabaan } \\
\text { Tindakan keperawatan } \\
\text { Sp2 : Memberikan informasi tentang } \\
\quad \text { cara pengunaan obat minum obat } \\
\text { Sp3 : memberikan informasi dampak } \\
\text { positif mengontol halusinasi } \\
\text { dengan cara bercakap - cakap } \\
\text { RTL : } \\
\text { Sp4 : Mengontrol halusinasi dengan } \\
\text { cara melakukan aktivitas }\end{array}$ & $\begin{array}{l}\text { S : Klien Senang dan } \\
\text { Antusias } \\
\text { O: } \\
\text { - } \text { klien mampu mengontrol } \\
\text { halusinasi dengan minum } \\
\text { obat secara teratur dengan } \\
\text { bantuan pengawas } \\
\text { yayasan. } \\
\text { - Klien mampu melakukan } \\
\text { komunikasi secara verbal } \\
\text { : asertif/bicara baik-baik } \\
\text { dengan motivasi. } \\
\text { A : Risiko Perilaku } \\
\text { Kekerasan (+). } \\
\text { P : } \\
\text { Latihan mengidentifikasi } \\
\text { halusinasinya; } \\
\text { frekuensi, watu terjadi, } \\
\text { sruasi pencetus, perasaan } \\
\text { dan respon halusinasi } \\
\text { 3x/hari } \\
\text { Latihan menghardik } \\
\text { halusinasi 3x/ hari } \\
\text { Latihan minum obat } \\
\text { dengan prinsip 6 benar } \\
\text { 2x/hari } \\
\text { Latihan komunikasi } \\
\text { secara verbal } \\
\text { asertif/bicara baik-baik } \\
\text { 3x/ hari. }\end{array}$ \\
\hline
\end{tabular}




\section{BAB 4 \\ PEMBAHASAN}

Setelah mahasiwa melaksanakan asuhan keperawatan kepada Ny. L dengan Gangguan Konsep Diri : Harga diri rendah kronis di Yayasan pemenang jiwa Sumatera Utara, maka mahasiswa pada $\mathrm{BAB}$ ini akan membahas kesenjangan antara teoritis dan tinjauan kasus. Pembahasan dimulai melalui tahapan prosess keperatan yaitu pengkajian, diagnosa keperawatan, perencanaan, pelaksanaan dan evalusi.

\subsection{Tahap Pengkajian}

Selama pengkajian dilakukan pengumpulan data dari beberapa sumber, yaitu dari pasien dan tenaga kesehatan di ruangan. Penulis mendapat sedikit kesulitan dalam menyimpulkan data karena keluarga pasien jarang mengunjungi pasien di yayasan pemenang jiwa. Maka penulis melakukan pendekatan kepada pasien melalui komunikasi teraupetik yang lebih terbuka membantu klien untuk memecahkan perasaannya dan juga melakukan observasi kepada pasien. Adapun upaya tersebut yaitu:

1. Melakukan pendekatan dan membina hubungan saling percaya diri pada klien agar klien lebih terbuka dan lebih percaya dengan menggunakan perasaan.

2. Mengadakan pengkajian klien dengan wawancara

3. Mengadakan pengkajian bertanya kepada pegawai yayasan pemenang jiwa.

Dalam pengkajian ini, penulis tidak menemukan kesenjangan karena ditemukan hal sama seperti diteori: Mengkritik diri sendiri, perasaan tidak mampu, pandangan hidup yang pesimis, penurunan produktivitas, penolakan terhadap kemampuan diri, malu terhadap diri sendiri, bicara ngawur, suka menyendiri, kontak mata kurang (Pardede, 2019).

\subsection{Tahap perencanaan}

Perencanaan dalam proses keperawatan lebih dikenal dengan rencana asuhan keperawatan yang merupakan tahap selanjutnya setelah pangkajian dan 
penentuan diagnosa keperawatan. Pada tahap perencanaan penulis hanya menyusun rencana tindakan keperawatan sesuai dengan pohon masalah keperawatan yaitu : Gangguan Konsep Diri : Harga diri rendah kronis (Keliat 2016).

Pada tahap ini antara tinjauan teoritis dan tinjauan kasus tidak ada kesenjangan sehingga penulis dapat melaksanakan tindakan seoptimal mungkin dan didukung dengan tersedianya sarana ruangan perawat yang baik dan adanya bimbingan dan petunjuk dari petugas kesehatan dari rumah sakit jiwa yang diberikan kepada penulis. Secara teoritis digunakan cara strategi pertemuan sesuai dengan diagnosa keperawatan yang muncul saat pengkajian. Adapun upaya yang dilakukan penulis yaitu :

Gangguan Konsep Diri : Harga diri rendah kronis

1. Harga Diri Rendah Kronis

1. Mengidentifikasi kemampuan dan aspek positif yang dimiliki pasien

a. Menilai kemampuan yang dapat digunakan

b. Menetapkan atau memilih kegiatan sesuai kemampuan

c. Melatih kegiatan sesuai kemampuan yang dipilih 1

2. Melatih kegiatan sesuai kemampuan yang dipilih 2

3. Melatih kegiatan sesuai kemampuan yang dipilih 3

4. Mengevalusi jadwal kegiatan harian pasien.

2. Isolasi Sosial

a. Menjelasan keuntungan dan keruguan memiliki teman

b. Melatih klien berkenalan dengan dua orang atau lebih

c. Melatih bercakap-cakap sambal melakukan kegiatan harian

d. Melatih berbicara social meminta sesuatu berbelanja dan sebagainya.

3. Halusinasi

a. Identifikasi isi, frekuensi, waktu terjadi, situasi pencetus, dan respon terhadap halusinasi

b. Mengontrol halusinasi dengan cara menghardik

c. Mengontrol Halusinasi dengan cara minum obat secara teratur 
d. Mengontrol halusinasi dengan cara bercakap - cakap dengan orang lain

e. Mengontrol halusinasi dengan cara melakukan aktifitas terjadwal

\subsection{Tahap Implementasi}

Pada tahap implementasi mahasiswa hanya mengatasi masalah keperawatan dengan diagnosa keperawatan Gangguan Konsep Diri : Harga diri rendah kronis. Pada diagnosa keperawatan Gangguan Konsep Diri : Harga diri rendah kronis dilakukan strategi pertemuan yaitu mengidentifikasi kemampuan dan aspek positif yang dimiliki pasien, menilai kemampuan yang dapat digunakan menetapkan/ memilih kegiatan sesuai kemampuan "melatih kegiatan sesuai kemampuan yang dipilih 1", melatih kegiatan sesuai kemampuan yang dpilih 2, dan melatih kegiatan sesuai kemampuan yang di pilih 3 (Pardede, Keliat, \& Yulia, 2015).

\subsection{Tahap evaluasi}

Pada tinjauan kasus evaluasi yang dihasilkan adalah :

1. Pasien mempercayai perawat sebagai terapis

2. Pasien dapat mengidentifikasi kemampuan dan aspek positif yang dimiliki

3. Pasien mampu menilai kemampuan yang dapat digunakan

4. Pasien mampu menetapkan/ memilih kegiatan sesuai kemampuan "melatih kegiatan sesuai kemampuan yang dipilih 1"

5. Pasien dapat melatih kegiatan sesuai kemampuan yang dpilih 2

6. Pasien dapat melatih kegiatan sesuai kemampuan yang di pilih 3 


\section{BAB 5}

\section{PENUTUP}

\subsection{Kesimpulan}

Setelah menguraikan tentang proses keperawatan pada Ny. L dan disimpulkan bahwa pasien dapat mengidentifikasi kemampuan dan aspek positif yang dimiliki dengan terapi yang di ajarkan oleh mahasiwa. Dimana pasien dapat melakukan kegiatan sesuai kemampuannya.

\subsection{Saran}

1. Bagi Perawat

Diharapkan perawat dapat menerapkan komunikasi terapeutik dalam pelaksanaan strategi pertemuan 1- 4 dalam memberikan tindakan sesuai SP pada klien dengan Gangguan konsep diri sensori : harga diri rendah sehingga dapat mempercepat proses pemulihan klien

2. Bagi Institusi Pendidikan

Dapat dijadikan sebagai acuan pembelajaran dalam meningkatkan bimbingan klinik kepada mahasiswa profesi ners sehingga mahasiswa semakin mampu dalam melakukan asuhan keperawatan pada pasien yang mengalami Gangguan konsep diri sensori : harga diri rendah. 


\section{DAFTAR PUSTAKA}

1. Asoka (Sub Akut Laki) RSKD Provinsi Maluku. Window Of Health: Jurnal Kesehatan, 345-351.Keliat, B. A. (2014). Proses Kesehatan Jiwa. Edisi 1. Jakarta : EGC. 1999 Https://Doi.Org/10.33368/Woh.V0i0.210

2. Dwi Saptina, C. H. A. N. D. R. A. (2020). Asuhan Keperawatan Pada Klien Skizofrenia Dengan Masalah Harga Diri Rendah Kronik (Doctoral Dissertation, Universitas Muhammadiyah Ponorogo). Http://Eprints.Umpo.Ac.Id/Id/Eprint/6116

3. Keliat, B. A., Akemat, S., Daulima, N. H. C., \& Nurhaeni, H. (2011). Keperawatan Kesehatan Jiwa Komunitas: CMHN (Basic Course). Jakarta: $E G C, 1-10$.

4. Kemenkes RI.(2019). Riset Kesehatan Dasar, Riskesdas. Jakarta: Kemenkes RI Https://Databoks.Katadata.Co.Id/Datapublish/2019/10/08/PersebaranPrevalensi-Skizofreniapsikosis-Di-Indonesia

5. Krissanti, A., \& Asti, A. D. (2019). Penerapan Terapi Okupasi: Berkebun Untuk Meningkatkan Harga Diri Pada Pasien Harga Diri Rendah Di Wilayah Puskesmas Sruweng. Proceeding of The URECOL, 630-636. Http://Repository.Urecol.Org/Index.Php/Proceeding/Article/View/701

6. Lete, G. R., Kusuma, F. H. D., \& Rosdiana, Y. (2019). Hubungan Antara Harga Diri Dengan Resiliensi Remaja Di Panti Asuhan Bakti Luhur Malang. Nursing News: Jurnal Ilmiah Keperawatan,4(1). Https://Publikasi.Unitri.Ac.Id/Index.Php/Fikes/Article/View/1436

7. Muhith, A. (2015). Pendidikan Keperawatan Jiwa: Teori Dan Aplikasi. Penerbit Andi.

8. Pardede, J. A. (2019). The Effects Acceptance and Aommitment Therapy and Health Education Adherence to Symptoms, Ability to Accept and Commit to Treatment and Compliance in Hallucinations Clients Mental Hospital of Medan, North Sumatra. J Psychol Psychiatry Stud, 1, 30-35.

9. Pardede, J. A., Keliat, B. A., \& Yulia, I. (2015). Kepatuhan Dan Komitmen Klien Skizofrenia Meningkat Setelah Diberikan Acceptance And Commitment Therapy Dan Pendidikan Kesehatan Kepatuhan Minum Obat. Jurnal Keperawatan Indonesia, 18(3), 157-166. Http://Jki.Ui.Ac.Id/Index.Php/Jki/Article/View/419

10. Pardede, J. A., Harjuliska, H., \& Ramadia, A. (2021). Self-Efficacy dan Peran Keluarga Berhubungan dengan Frekuensi Kekambuhan Pasien Skizofrenia. Jurnal Ilmu Keperawatan Jiwa, 4(1), 57-66. http://dx.doi.org/10.32584/jikj.v4i1.846 
11. Pardede, J. A., Keliat, B. A., \& Wardani, I. Y. (2013). Pengaruh Acceptance And Commitment Therapy Dan Pendidikan Kesehatan Kepatuhan Minum Obat Terhadap Gejala, Kemampuan Berkomitmen Pada Pengobatan Dan Kepatuhan Pasien Skizofrenia. Tesis. FIK UI.

12. Pardede, J. A., Keliat, B. A., \& Wardani, I. Y. (2020). The Symptoms of Low Self-Esteem Decline after Being Given Acceptance and Commitment Therapy. Adv Practice Nurs, 5, 170. doi: 10.37421/apn.2020.05.170

13. Pardede, J. A., Ariyo, A., \& Purba, J. M. (2020). Self Efficacy Related to Family Stress in Schizophrenia Patients. Jurnal Keperawatan, 12(4), 831838. https://doi.org/10.32583/keperawatan.v12i4.1010

14. Pardede, J. A., \& Hasibuan, E. K. (2020). Lamanya Perawatan Pasien Skizofrenia Rawat Jalan Dengan Tingkat Stres Keluarga. Indonesian Trust Health Journal, 3(1), 283-288. https://doi.org/10.37104/ithj.v3i1.49

15. Pardede, J. A., Hamid, A. Y. S., \& Putri, Y. S. E. (2020). Application of Social Skill Training using Hildegard Peplau Theory Approach to Reducing Symptoms and the Capability of Social Isolation Patients. Jurnal Keperawatan, 12(3), 327-340. https://doi.org/10.32583/keperawatan.v12i3.782

16. Prabowo, E. (2014). Konsep \& Aplikasi Asuhan Keperawatan Jiwa.

17. Pramujiwati, D., Keliat, B. A., \& Wardani, I. Y. (2013). Pemberdayaan Keluarga Dan Kader Kesehatan Jiwa Dalam Penanganan Pasien Harga Diri Rendah Kronik Dengan Pendekatan Model Precede L. Green Di Rw 06, 07 Dan 10 Tanah Baru Bogor Utara. Jurnal Keperawatan Jiwa, 1(2). Https://Doi.Org/10.26714/Jkj.1.2.2013.\%25p

18. Rahmawati, I. N. (2018). Asuhan Keperawatan Pada Pasien Gangguan Persepsi Sensori: Halusinasi Dengan Penerapan Kombinasi Terapi Aktivitas Secara Terjadwal Di Wisma Baladewa Rsj Prof Dr Soerojo Magelang Doctoral Dissertation, Stikes Muhammadiyah Gombong. Http://Elib.Stikesmuhgombong.Ac.Id/Id/Eprint/870

19. Rokhimmah, Y., \& Rahayu, D. A. (2020). Penurunan Harga Diri Rendah Dengan Menggunakan Penerapan Terapi Okupasi (Berkebun).Ners Muda, 1(1), 18-22. Https://Doi.Org/10.26714/Nm.V1i1.5493

20. Sitanggang, R., Pardede, J. A., Damanik, R. K., \& Simanullang, R. H. (2021). The Effect Of Cognitive Therapy On Changes In Self-Esteem On Schizophrenia Patients. European Journal Of Molecular \& Clinical Medicine, 7(11), 2696-2701. 
21. Tuasikal, H., Siauta, M., \& Embuai, S. (2019). Upaya Peningkatan Harga Diri Rendah Dengan Terapi Aktivitas Kelompok (Stimulasi Persepsi) Di Ruang

22. Wandono, W. A., \& Arum Pratiwi, S. (2017). Upaya Peningkatan Harga Diri Rendah Pada Pasien Depresi (Doctoral Dissertation, Universitas Muhammadiyah Surakarta).Http://Eprints.Ums.Ac.Id/Id/Eprint/52383

23. WHO, (2019). Schizophrenia. Retrieved From. Https://Www.Who.Int/NewsRoom/Fact-Sheets/\%20detail/Schizophrenia

24. Widianti, E., Keliat, B. A., \& Wardhani, I. Y. (2017). Aplikasi Terapi Spesialis Keperawatan Jiwa Pada Pasien Skizofrenia Dengan Harga Diri Rendah Kronis Di RSMM Jawa Barat. Jurnal Pendidikan Keperawatan Indonesia, 3(1), 83-99. Https://Doi.Org/10.17509/Jpki.V3i1.7489

25. Yusuf, A Dkk. (2015). Buku Ajar Keperawatan Kesehatan Jiwa. Jakarta Salemba Medika. Http://Eprints.Umpo.Ac.Id/6107/ 